\title{
Impact of organic nitrates on urban ozone production
}

\author{
D. K. Farmer ${ }^{1, *}$, A. E. Perring ${ }^{1, * *}$, P. J. Wooldridge ${ }^{1}$, D. R. Blake ${ }^{4}$, A. Baker ${ }^{4}$, S. Meinardi ${ }^{4}$, L. G. Huey ${ }^{5}$, D. Tanner ${ }^{5}$, \\ O. Vargas ${ }^{5}$, and R. C. Cohen ${ }^{1,2,3}$ \\ ${ }^{1}$ Department of Chemistry, University of California Berkeley, Berkeley, CA, 94720, USA \\ ${ }^{2}$ Department of Earth and Planetary Science, University of California Berkeley, Berkeley, CA, 94720, USA \\ ${ }^{3}$ Environmental Technologies Division, Lawrence Berkeley National Labs, Berkeley, CA, 94720, USA \\ ${ }^{4}$ Department of Earth System Science, University of California Irvine, Irvine, CA, 92697, USA \\ ${ }^{5}$ School of Earth and Atmospheric Sciences, Georgia Institute of Technology, Atlanta, GA, 30332, USA \\ *now at: Cooperative Institute for Research in Environmental Sciences and Department of Chemistry, University of Colorado, \\ Boulder, CO, 80309, USA \\ *** now at: Chemical Sciences Division, Earth System Research Laboratory, National Oceanic and \\ Atmospheric Administration, Boulder, Colorado and Cooperative Institute for Research in Environmental Sciences, \\ University of Colorado, Boulder, Colorado, USA
}

Received: 20 July 2010 - Published in Atmos. Chem. Phys. Discuss.: 11 October 2010

Revised: 8 February 2011 - Accepted: 26 April 2011 - Published: 4 May 2011

\begin{abstract}
Urban $\mathrm{O}_{3}$ is produced by photochemical chain reactions that amplify background $\mathrm{O}_{3}$ in mixtures of gaseous nitrogen oxides $\left(\mathrm{NO}_{\mathrm{x}}\right)$ and organic molecules. Current thinking treats $\mathrm{NO}_{\mathrm{x}}$ and organics as independent variables that limit $\mathrm{O}_{3}$ production depending on the $\mathrm{NO}_{\mathrm{x}}$ to organic ratio; in this paradigm, reducing organics either has no effect or reduces $\mathrm{O}_{3}$. We describe a theoretical counterexample where $\mathrm{NO}_{\mathrm{x}}$ and organics are strongly coupled and reducing organics increases $\mathrm{O}_{3}$ production, and illustrate the example with observations from Mexico City. This effect arises from chain termination in the $\mathrm{HO}_{\mathrm{x}}$ and $\mathrm{NO}_{\mathrm{x}}$ cycles via organic nitrate production. We show that reductions in VOC reactivity that inadvertently reduce organic nitrate production rates will be counterproductive without concurrent reductions in $\mathrm{NO}_{\mathrm{x}}$ or other organics.
\end{abstract}

\section{Introduction}

High concentrations of ozone $\left(\mathrm{O}_{3}\right)$ at the Earth's surface are widely recognized as unhealthy and are a target for public policies aimed at reducing occurrence of asthma and other cardiopulmonary diseases and at improving crop yields (Bell et al., 2005; Booker et al., 2009; Selin et al., 2009; Silverman et al., 2010). Production of surface $\mathrm{O}_{3}$ is typically consid-

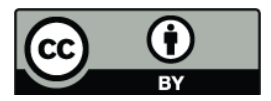

Correspondence to: R. C. Cohen (rccohen@berkeley.edu) ered limited by either gas phase (volatile) organic molecules (VOC) or nitrogen oxides $\left(\mathrm{NO}_{\mathrm{x}}=\mathrm{NO}+\mathrm{NO}_{2}\right)$, and control strategies to reduce $\mathrm{O}_{3}$ typically target the limiting reagent. Here, we demonstrate that the production of organic nitrates (molecules of the form $\mathrm{RONO}_{2}$ ) during oxidation of organics confounds the usual assumption that organics and $\mathrm{NO}_{\mathrm{x}}$ are independent variables that can be considered separately in ozone control strategies, and show that in some cases organic reductions that are presumed in the standard conceptual model to be effective at reducing ozone can be counterproductive and result in ozone increases.

Tropospheric $\mathrm{O}_{3}$ is produced by the catalytic oxidation of gas phase organic compounds in the presence of $\mathrm{NO}_{\mathrm{x}}$. Initiation of the catalysis begins with the production of radicals (most often $\mathrm{OH}$ ) from either sunlight-driven photolysis or the reaction of $\mathrm{O}_{3}$ with alkenes. $\mathrm{OH}$ reacts with $\mathrm{VOC}$ or $\mathrm{CO}$, producing peroxy radicals $\left(\mathrm{HO}_{2}, \mathrm{RO}_{2}\right)$. These peroxy radicals oxidize $\mathrm{NO}$ to $\mathrm{NO}_{2}$, which is then photolyzed to produce the $\mathrm{O}\left({ }^{3} \mathrm{P}\right)$ atoms that react with $\mathrm{O}_{2}$ to form $\mathrm{O}_{3}$ :

$$
\begin{aligned}
& \mathrm{NO}+\mathrm{HO}_{2} \rightarrow \mathrm{NO}_{2}+\mathrm{OH} \\
& \mathrm{NO}+\mathrm{RO}_{2} \rightarrow \mathrm{NO}_{2}+\mathrm{RO} \\
& \mathrm{NO}_{2}+\mathrm{hv} \rightarrow \mathrm{NO}+\mathrm{O}\left({ }^{3} \mathrm{P}\right) \\
& \mathrm{O}\left({ }^{3} \mathrm{P}\right)+\mathrm{O}_{2} \rightarrow \mathrm{O}_{3}
\end{aligned}
$$

In the presence of oxygen, the alkoxy radical (RO) produced in Reaction (R2a) typically isomerizes or decomposes,

Published by Copernicus Publications on behalf of the European Geosciences Union. 
resulting in production of $\mathrm{RO}_{2}$ or $\mathrm{HO}_{2}$. Reaction of $\mathrm{HO}_{2}$ with $\mathrm{NO}$ to reform $\mathrm{OH}$ completes the chain.

Ozone production (hereafter $P_{\mathrm{O}_{3}}$ ) by this radical chain continues until termination. Most often, we consider the effects of two classes of termination reactions. First, in air with low $\mathrm{NO}_{\mathrm{x}}$ to organic ratios $\left(\mathrm{NO}_{\mathrm{x}}\right.$-limited regime), peroxide formation (R5) dominates chain termination:

$\mathrm{RO}_{2}+\mathrm{HO}_{2} \rightarrow \mathrm{ROOH}+\mathrm{O}_{2}$

In this regime, the addition of $\mathrm{NO}_{\mathrm{x}}$ increases $\mathrm{O}_{3}$ production by enhancing the rates of (R1) and (R2a), while addition of VOC has little effect on $\mathrm{O}_{3}$ production rates as nearly every $\mathrm{OH}$ formed is already reacting with a VOC. In air with high $\mathrm{NO}_{\mathrm{x}}$ to organic ratios (variously called VOC limited, $\mathrm{NO}_{\mathrm{x}}$ saturated or $\mathrm{NO}_{\mathrm{x}}$ suppressed), nitric acid $\left(\mathrm{HNO}_{3}\right)$ formation is the primary chain termination step:

$\mathrm{OH}+\mathrm{NO}_{2} \rightarrow \mathrm{HNO}_{3}$

In this regime, the addition of $\mathrm{NO}_{\mathrm{x}}$ decreases $\mathrm{O}_{3}$ production because $\mathrm{NO}_{2}$ effectively competes with the available organics for $\mathrm{OH}$. Ozone production rates increase when organics are added or when $\mathrm{NO}_{\mathrm{x}}$ is removed. As a result of these competing chain termination reactions, $P_{\mathrm{O}_{3}}$ varies non-linearly with $\mathrm{NO}_{\mathrm{x}}$ at constant VOC (Liu et al., 1988; Thornton et al., 2002; Murphy et al., 2007).

Chain termination can also occur in reactions that result from combining $\mathrm{RO}_{2}$ and $\mathrm{NO}_{\mathrm{x}}$ radicals to form either peroxy acyl nitrates $\left(\mathrm{PNs}=\mathrm{RC}(\mathrm{O}) \mathrm{O}_{2} \mathrm{NO}_{2}\right.$, Reaction $\mathrm{R} 7$ ) or alkyl and multifunctional nitrates $\left(\mathrm{ANs}=\mathrm{RONO}_{2}\right.$, hereafter referred to as "alkyl nitrates", Reaction R2b):

$\mathrm{RC}(\mathrm{O}) \mathrm{O}_{2}+\mathrm{NO}_{2} \leftrightarrow \mathrm{RC}(\mathrm{O}) \mathrm{O}_{2} \mathrm{NO}_{2}$

$\mathrm{NO}+\mathrm{RO}_{2} \rightarrow \mathrm{RONO}_{2}$

PNs are temporary reservoirs that release most of the $\mathrm{NO}_{\mathrm{x}}$ soon (minutes to hours) after formation. On regional and global scales it is widely understood that PN formation redistributes $\mathrm{NO}_{\mathrm{x}}$, decreasing $\mathrm{NO}_{\mathrm{x}}$ in the urban core and increasing $\mathrm{NO}_{\mathrm{x}}$ downwind (Singh et al., 1981; Moxim et al., 1996; Heald et al., 2003; Hudman et al., 2004).

In contrast, ANs have been, with few exceptions (Shepson et al., 1993; Horowitz et al., 2007; Ito et al., 2009; Perring et al., 2009), considered nearly permanent sinks for $\mathrm{NO}_{\mathrm{x}}$ with consequences that are only local. Specific effects of AN formation on global- and continental-scale $\mathrm{O}_{3}$ in response to climate change have been the focus of recent model studies (Wu et al., 2007; Ito et al., 2009; Weaver et al., 2009). However, little attention has been paid to effects of AN formation on urban $\mathrm{O}_{3}$ and thus $\mathrm{O}_{3}$ control strategies. This is true both for simplified analytical models which often neglect the reactions leading to AN formation and for computationally intensive chemical transport models which represent chemistry using lumped mechanistic elements that reduce computing demands but do not accurately represent AN production.
The main goal of this paper is to analyze a simplified model of atmospheric chemistry, thus providing intuition about interpreting the combined effects of VOC reactivity and alkyl nitrate branching ratios in more complex chemical transport models representing urban air pollution and investigating possible control strategies. We also show that the hypothetical scenarios we discuss have relevance to thinking about a real world situation using analysis of observations from Mexico City.

\section{Methods and measurements}

\subsection{Site}

Measurements were made at the $\mathrm{T} 1$ site at the Universidad Tecnical de Tecámac (UTTEC) in Tecámac, MX $\left(19.703^{\circ} \mathrm{N}\right.$ latitude, $98.982^{\circ} \mathrm{W}$ longitude, $2273 \mathrm{~m}$ elevation) as part of the MILAGRO (Megacity Impacts on Local, Global and Regional Environments) campaign. Inlets and instruments were located on the university campus, which is $\sim 30 \mathrm{~km}$ to the north of Mexico City, and lies between a large, unmanaged field and a large road that was a few hundred meters uphill and to the north of the site, typically downwind during the daytime. The site was located such that prevailing winds should be a few hours downwind from downtown Mexico City. Inlets for $\mathrm{NO}_{\mathrm{y}, i}$ species $\left(\mathrm{NO}_{2}, \Sigma \mathrm{PNs}\right.$, $\Sigma \mathrm{ANs}_{\text {(gas+aerosol) }}$, and $\mathrm{HNO}_{3 \text { (gas+aerosol) }}$ ), $\mathrm{O}_{3}$, and $\mathrm{CO}$ were co-located approximately $10 \mathrm{~m}$ above ground level; instruments were kept in temperature-controlled containers. Measurements described in this paper were taken between 17 March and 29 March 2006.The site was characterized by mid-afternoon average temperature highs of $25^{\circ} \mathrm{C}$ and presunrise lows of $10^{\circ} \mathrm{C}$. Thunderstorms and precipitation were observed on several late-afternoons. The boundary layer grew rapidly in the mid-morning to $2-3 \mathrm{~km}$ (Fast et al., 2007).

\subsection{Instrumentation}

$\mathrm{NO}_{2}, \Sigma$ PNs, $\Sigma \mathrm{ANs}_{\text {(gas+aerosol) }}$, and $\mathrm{HNO}_{3 \text { (gas+aerosol) were }}$ measured by the UC Berkeley thermal dissociation-laser induced fluorescence (TD-LIF) detector (Day et al., 2002). Briefly, air is pulled through a heated PFA inlet into a resistively-heated quartz tube, or oven. Classes of $\mathrm{NO}_{\mathrm{y} i}$ species are thermally dissociated to $\mathrm{NO}_{2}$ and an accompanying radical at temperatures characteristic of their bond energies. For example, in the configuration used during the MILAGRO campaign, peroxy and peroxy acyl nitrates $(\Sigma \mathrm{PNs}$, $\Sigma \mathrm{R}_{i} \mathrm{O}_{2} \mathrm{NO}_{2}$ ) dissociate to $\mathrm{NO}_{2}$ and $\mathrm{RO}_{2}$ radicals at $180^{\circ} \mathrm{C}$, alkyl and multifunctional nitrates $\left(\Sigma \mathrm{ANs}, \Sigma \mathrm{R}_{i} \mathrm{ONO}_{2}\right)$ dissociate to $\mathrm{NO}_{2}$ and $\mathrm{RO}$ radicals by $360^{\circ} \mathrm{C}$, and $\mathrm{HNO}_{3}$ dissociates to $\mathrm{NO}_{2}$ and $\mathrm{OH}$ at $620^{\circ} \mathrm{C}$. The difference in $\mathrm{NO}_{2}$ detected in adjacent channels is thus the sum of each class: the $\Sigma$ PNs mixing ratio is the difference in $\mathrm{NO}_{2}$ signal detected in a $180^{\circ} \mathrm{C}$ oven and $\mathrm{NO}_{2}$ detected in an unheated oven. $\mathrm{HONO}$ 
is not detected in this system and $\mathrm{N}_{2} \mathrm{O}_{5}$ dissociates in the $\Sigma$ PNs channel. Semi-volatile particle-phase organic nitrates are expected to dissociate in the $\Sigma$ ANs channel, and semivolatile particulate $\mathrm{HNO}_{3}$ (i.e., $\mathrm{NH}_{4} \mathrm{NO}_{3}$ ) dissociates in the $\mathrm{HNO}_{3}$ channels with unit efficiency (Rollins et al., 2010). During these experiments, a glass pinhole was placed at the entrance to the inlet to create a large pressure drop before air entered the ovens. This pressure drop minimized the effects of secondary chemistry on the observed concentrations. As a result, corrections that have been required at high $\mathrm{NO}$ or high $\mathrm{O}_{3}$ for other inlet configurations were unnecessary.

$\mathrm{NO}_{2}$ is detected by laser-induced fluorescence by exciting ground-state $\mathrm{NO}_{2}$ radicals at $408 \mathrm{~nm}$ with a littrow configuration tunable diode laser (Toptica DL100). Laser power was at $9 \mathrm{~mW}$ for the duration of the campaign, and the linewidth is $<1 \mathrm{MHz}$. Measurements were taken at $1 \mathrm{~Hz}$, averaged to three minutes and interpolated to a common time basis.

The TD-LIF was maintained in a 2 oven- 2 cell mode in which $\mathrm{NO}_{2}$ signal is detected from pairs of oven temperatures in two cells for approximately $25 \mathrm{~min}$ before the oven temperatures were ramped to the next pair of temperatures. For example, the two ovens would be set at $180^{\circ} \mathrm{C}$ and $360^{\circ} \mathrm{C}$ to measure $\Sigma$ ANs, and then cooled to ambient and $180^{\circ} \mathrm{C}$ to measure $\mathrm{NO}_{2}$ and $\Sigma$ PNs. Oven temperatures were overlapped during the ramping cycles at least once a day to intercompare and confirm that ovens set at identical temperatures detected identical $\mathrm{NO}_{2}$. The duty cycle to directly measure the full suite of $\mathrm{NO}_{\mathrm{y} i}$ classes was $100 \mathrm{~min}$. Note that $\Sigma$ PNs and $\mathrm{NO}_{2}$ were simultaneously measured for $50 \mathrm{~min}$ of each ramp cycle. For this analysis, data were interpolated to obtain a simultaneous set of $\mathrm{NO}_{\mathrm{yi}}$ measurements. Comparison of the $\Sigma \mathrm{PN}$ and $\Sigma \mathrm{AN}$ measurements using TD-LIF shows they have accuracy comparable to independent methods (Perring et al., 2010; Wooldridge et al., 2010).

$\mathrm{O}_{3}$ was measured by a commercial UV photometric $\mathrm{O}_{3}$ analyzer (TECO Model 49C). CO was measured by a modified commercial non-dispersed IR adsorption instrument (Thermo Environmental Systems, Model 48C) (Parrish et al., 1994). NO was measured by a chemiluminescence detector (Ryerson et al., 2000). VOCs were measured by ProtonTransfer Ion Trap Mass Spectrometry (Warneke et al., 2005), in situ gas chromatography, and ex situ GC analysis from canister samples.

\subsection{Data analysis}

We calculated observed VOC reactivity $\left(\mathrm{s}^{-1}\right)$ as the sum of VOC mixing ratios, including $\mathrm{CH}_{4}$, scaled by their $\mathrm{OH}$ reactivity:

$\tau_{\mathrm{VOC}}=\sum_{i} k_{\mathrm{OH}+\mathrm{VOC}_{\mathrm{i}}}\left[\mathrm{VOC}_{i}\right]$

Total $\mathrm{OH}$ reactivity was calculated by including $\mathrm{CO}, \mathrm{NO}_{\mathrm{x}}$, $\mathrm{HNO}_{3}, \mathrm{SO}_{2}, \mathrm{O}_{3}$, peroxides and peroxy radicals.

Rosen et al. (2004) described in detail how the observed branching ratio is calculated from the ratio of $\mathrm{O}_{\mathrm{x}}\left(\mathrm{O}_{3}+\mathrm{NO}_{2}\right)$ versus alkyl nitrates. Briefly, the instantaneous production rates of alkyl nitrates and $\mathrm{O}_{3}\left(P_{\Sigma \text { ANs }}\right.$ and $P_{\mathrm{O}_{3}}$, respectively) can be described by

$$
\begin{aligned}
& P_{\Sigma \mathrm{ANs}}=\sum_{i} \alpha_{i} k_{\mathrm{OH}+\mathrm{VOC}_{i}}[\mathrm{OH}]\left[\mathrm{VOC}_{i}\right] \\
& P_{\mathrm{O}_{3}}=\sum_{i} \gamma_{i}\left(1-\alpha_{i}\right) k_{\mathrm{OH}+\mathrm{VOC}_{i}}[\mathrm{OH}]\left[\mathrm{VOC}_{i}\right]
\end{aligned}
$$

where, for an individual $\mathrm{VOC}_{i}, \alpha_{i}$ is the branching ratio and $\gamma_{i}$ the number of $\mathrm{O}_{3}$ produced, typically 2 (Rosen et al., 2004). Assuming that the VOC mixture is dominated by species with $\gamma_{i}=2$ and that the effective branching ratio of the entire VOC mix $(\alpha)$ is relatively small $(\ll 1), \alpha$ can be related to the ratio of $\mathrm{O}_{3}$ to $\Sigma \mathrm{AN}$ production (Rosen et al., 2004). If near enough to the VOC source to ignore deposition and entrainment, the ratio of $\mathrm{O}_{3}$ to $\Sigma \mathrm{AN}$ production can be approximated by observed changes $(\Delta)$ in $\mathrm{O}_{\mathrm{x}}$ and $\Sigma$ ANs:

$$
\frac{\Delta \mathrm{O}_{\mathrm{x}}}{\Delta \Sigma \mathrm{ANs}} \approx \frac{P_{\mathrm{O}_{3}}}{P_{\Sigma \mathrm{ANs}}} \approx \frac{2(1-\alpha)}{\alpha} \approx \frac{2}{\alpha}
$$

Using this relationship, we determined the effective branching ratio for the field site from observed $\mathrm{O}_{3}, \mathrm{NO}_{2}$ and $\Sigma$ ANs. Note that this calculation assumes that all ANs observed by the TD-LIF are formed in the gas-phase through Reaction (R2b), whether they were observed in the gas or particle phase.

We calculate the VOC precursors of the observed $\Sigma$ ANs following Rosen et al. (2004). The relative contribution of each VOC to an instantaneous $\Sigma$ AN production was calculated from the VOC reactivity of the individual species $\left(\tau_{\mathrm{VOC}, i}\right)$ scaled by the species' branching ratio $\left(\alpha_{i}\right)$ and rate constant with respect to $\mathrm{NO}\left(k_{\mathrm{NO}+\mathrm{RO}_{2}}\right)$, normalized by the total production rate calculated as the sum over all $\Sigma \mathrm{AN}$ production (Eq. 5):

$$
\frac{P_{\mathrm{AN}, i}}{P_{\Sigma \mathrm{ANs}}}=\frac{\tau_{\mathrm{VOC}, i} k_{\mathrm{NO}+\mathrm{RO}_{2}} \alpha_{i}}{\sum_{i} \tau_{\mathrm{VOC}, i} k_{\mathrm{NO}+\mathrm{RO}_{2}} \alpha_{i}}
$$

We use average afternoon (12:00 p.m.-06:00 p.m.) concentrations of each observed species to represent VOC reactivity. Several VOC species likely to be contributors to alkyl nitrate formation were not measured; to account for these, expected average afternoon mixing ratios were estimated from mixing ratios and relative abundance observed in the Mexico City region during the MCMA 2003 campaign (Dunlea et al., 2007) (starred entries in Table S1). These compounds represent $<15 \%$ of the total $\mathrm{OH}$ reactivity. Mixing ratios, branching ratios and rate constants used in this analysis are summarized in Table S1. This analysis includes observed $\Sigma$ ANs as precursors, which are expected to react with $\mathrm{OH}$ radicals to become further functionalized (Rosen et al., 2004) and possibly form di-nitrates. 


\subsection{Observations}

Daytime total $\mathrm{OH}$ reactivity ranged from $3-34 \mathrm{~s}^{-1}$, with $\mathrm{NO}_{2}$ comprising $9-35 \%$ of the total during the day, and VOC and $\mathrm{CO}$ ranging $43-69 \%$ of the total. The contributions to the afternoon reactivity were due to $\mathrm{CO}(31 \%), \mathrm{CH}_{4}$ (7\%), saturated hydrocarbons (13\%), unsaturated hydrocarbons ( $29 \%$ ), $\Sigma$ ANs (5\%), and $\mathrm{C}_{6}-\mathrm{C}_{11}$ aromatics (7\%), with aldehydes, ketones, alcohols, and formaldehyde making up the remaining $8 \%$. Aromatic concentrations largely follow the diurnal cycle of VOC reactivity but they contribute a larger fraction of VOC reactivity in the evening and morning than at midday ( $12 \%$ vs. $7 \%$ ) indicating that they are a larger fraction of primary emissions. While benzene and toluene each comprise a third of observed nocturnal aromatics, they account for almost all (benzene $56 \%$, toluene $43 \%$ ) aromatic concentrations at peak $\mathrm{O}_{3}$ (02:00 p.m.). Daily $\Sigma \mathrm{AN}$ maxima were observed at noon and $\mathrm{O}_{3}$ maxima were observed at $\sim 02: 00$ p.m. $\Sigma$ ANs were correlated with $\mathrm{O}_{\mathrm{x}}\left(=\mathrm{O}_{3}+\mathrm{NO}_{2}\right)$, consistent with previous observations in urban and rural environments (Day et al., 2003; Rosen et al., 2004; Cleary et al., 2005) and with our analysis of export in the Mexico city plume (Perring et al., 2010).

Relative contributions of VOC classes to $\mathrm{OH}$ reactivity and $\Sigma$ AN production are shown in Fig. S1. As AN branching ratios for aromatics are less well established than for some of the other categories, the contribution of aromatics to ANs is calculated with two different estimated yields to provide an upper and lower limit of their contribution. The lower branching ratios are described in the table $(5 \%$ for benzene and toluene, $10 \%$ for xylene, $8 \%$ for all other aromatics), and are used throughout the paper unless otherwise specified. The upper estimates for aromatic branching ratios are $5 \%$ for benzene and toluene, $10 \%$ for xylene and $25 \%$ for all other aromatics.

\section{Discussion}

\subsection{Analysis}

The effects of AN chemistry on $P_{\mathrm{O}_{3}}$ can be represented by a quadratic equation (Eqs. 6-12) that describes the coupled kinetics of Reactions (R1-R7) (Murphy et al., 2006). The equation describes $P_{\mathrm{O}_{3}}$ at a single time of day, and is derived from the understanding that $\mathrm{HO}_{\mathrm{x}}\left(=\mathrm{OH}+\mathrm{HO}_{2}+\mathrm{RO}_{2}\right)$ radicals are in steady state. Using this equation is a reasonable approximation to the effects that would be observed in a fully coupled chemical transport model as peak $P_{\mathrm{O}_{3}}$ occurs at noon and is strongly correlated with observed $\mathrm{O}_{3}$ maxima. As $\mathrm{HO}_{\mathrm{x}}$ is assumed to be in steady-state, the production and loss rates are equal:

$$
\begin{aligned}
& P_{\mathrm{HO}_{\mathrm{x}}}=L_{\mathrm{HO}_{\mathrm{x}}}=k_{\mathrm{OH}+\mathrm{NO}_{2}} \times[\mathrm{OH}]\left[\mathrm{NO}_{2}\right]+\alpha \times k_{\mathrm{NO}+\mathrm{RO}_{2}} \\
& \quad \times[\mathrm{NO}]\left[\mathrm{RO}_{2}\right]+2 k_{\mathrm{HO}_{2}+\mathrm{HO}_{2}} \times\left[\mathrm{HO}_{2}\right]\left[\mathrm{HO}_{2}\right]+2 k_{\mathrm{RO}_{2}+\mathrm{HO}_{2}} \\
& \quad \times\left[\mathrm{HO}_{2}\right]\left[\mathrm{RO}_{2}\right]+2 k_{\mathrm{RO}_{2}+\mathrm{RO}_{2}} \times\left[\mathrm{RO}_{2}\right]\left[\mathrm{RO}_{2}\right]
\end{aligned}
$$

As described by Murphy et al. (2006), under conditions of rapid ozone production in which chain propagation dominates, every $\mathrm{RO}_{2}$ produced via VOC oxidation by $\mathrm{OH}$ reacts with an $\mathrm{NO}$ radical (Reaction R2) and results in an $\mathrm{HO}_{2}$ radical following reaction of the alkoxy radical with $\mathrm{O}_{2}$. Thus, $\mathrm{HO}_{\mathrm{x}}$ can be expressed as:

$$
\left[\mathrm{HO}_{2}\right] \approx\left[\mathrm{RO}_{2}\right] \approx \frac{\tau_{\mathrm{VOC}}[\mathrm{OH}]}{(1-\alpha) k_{\mathrm{NO}+\mathrm{RO}_{2}}[\mathrm{NO}]}
$$

Following Murphy et al. (2006), the instantaneous $P_{\mathrm{O}_{3}}$ is approximated from Eq. (3):

$$
\begin{aligned}
P_{\mathrm{O}_{3}} & =k_{\mathrm{HO}_{2}+\mathrm{NO}}\left[\mathrm{HO}_{2}\right][\mathrm{NO}]+k_{\mathrm{RO}_{2}+\mathrm{NO}}\left[\mathrm{RO}_{2}\right][\mathrm{NO}] \\
& =2 \times \tau_{\mathrm{VOC}} \times\left[\mathrm{OH}_{\text {calc }}\right]
\end{aligned}
$$

Combining the above equations and solving for $\mathrm{OH}$, one finds:

$\mathrm{OH}_{\mathrm{calc}}=\frac{-b \pm \sqrt{b^{2}-4 a c}}{2 a}$

where

$$
\begin{aligned}
a & =\left(2 k_{\mathrm{HO}_{2}+\mathrm{HO}_{2}}+2 k_{\mathrm{RO}_{2}+\mathrm{HO}_{2}}+2 k_{\mathrm{RO}_{2}+\mathrm{RO}_{2}}\right) \\
& \times\left(\frac{\tau_{\mathrm{VOC}}}{(1-\alpha) \times k_{\mathrm{NO}+\mathrm{RO}_{2}} \times[\mathrm{NO}]}\right)^{2} \\
b & =k_{\mathrm{OH}+\mathrm{NO}_{2}} \times\left[\mathrm{NO}_{2}\right]+\frac{\alpha \times k_{\mathrm{NO}+\mathrm{RO}_{2}} \times \tau_{\mathrm{VOC}}}{(1-\alpha) k_{\mathrm{NO}+\mathrm{RO}_{2}}} \\
c & =-P_{\mathrm{HO}_{\mathrm{x}}}
\end{aligned}
$$

In the above equations, $\tau_{\mathrm{VOC}}$ is the $\mathrm{VOC}$ reactivity to $\mathrm{OH}$ $\left(\mathrm{s}^{-1}\right), \alpha$ is the effective $\mathrm{AN}$ branching ratio for the ambient mix of VOC and $P_{\mathrm{HO}_{\mathrm{x}}}$ is the $\mathrm{HO}_{\mathrm{x}}$ production rate. Rate constants for $\mathrm{HO}_{2}$ self-reaction $\left(k_{\mathrm{HO}_{2}}+\mathrm{HO}_{2}\right), \mathrm{HO}_{2}-\mathrm{RO}_{2}$ reactions $\left(k_{\mathrm{HO}_{2}}+\mathrm{RO}_{2}\right)$ and $\mathrm{RO}_{2}$ self-reaction $\left(k_{\left.\mathrm{RO}_{2}+\mathrm{RO}_{2}\right)}\right)$ were taken from the 15th JPL evaluation (Sander et al., 2006) and are $2.74 \times 10^{-12}, 8 \times 10^{-12}$ and $6.8 \times 10^{-14} \mathrm{~cm}^{3} \mathrm{molec}^{-1} \mathrm{~s}^{-1}$, respectively. These numbers assume that rates for $\mathrm{C}_{2} \mathrm{H}_{5} \mathrm{O}_{2}$ are exemplary of all $\mathrm{RO}_{2}$, as described in Perring et al. (2001).

\subsection{Theoretical examples}

Figure 1a-d shows calculations of $P_{\mathrm{O}_{3}}$ using this equation with $P_{\mathrm{HO}_{\mathrm{x}}}=3.5 \times 10^{6} \mathrm{molec}^{-3} \mathrm{~s}^{-1}$ and $\alpha=0,0.035$, 0.07 and 0.13 . An increase in $\alpha$ causes a decrease in $P_{\mathrm{O} 3}$ independent of VOC reactivity. At larger VOC reactivity the effect is slightly larger. For example, doubling $\alpha$ from $3.5 \%$ to $7 \%$ with a VOC reactivity of $5 \mathrm{~s}^{-1}$ causes a $21 \%$ decrease in peak $P_{\mathrm{O}_{3}}$, but the same change in $\alpha$ at a VOC reactivity of $10 \mathrm{~s}^{-1}$ causes a $26 \%$ decrease in $P_{\mathrm{O}_{3}}$. The effect of $\alpha$ on maximum $P_{\mathrm{O}_{3}}$ can be approximated as $(1-\alpha)^{2 \times \text { chain length }}$, where chain length is the ratio of propagation to initiation rates for $\mathrm{O}_{3}$ formation through the steps described above. This is useful to keep in mind as it helps to explain why $\mathrm{RONO}_{2}$ production is not important at high $\mathrm{NO}_{\mathrm{x}}$ where chain lengths 

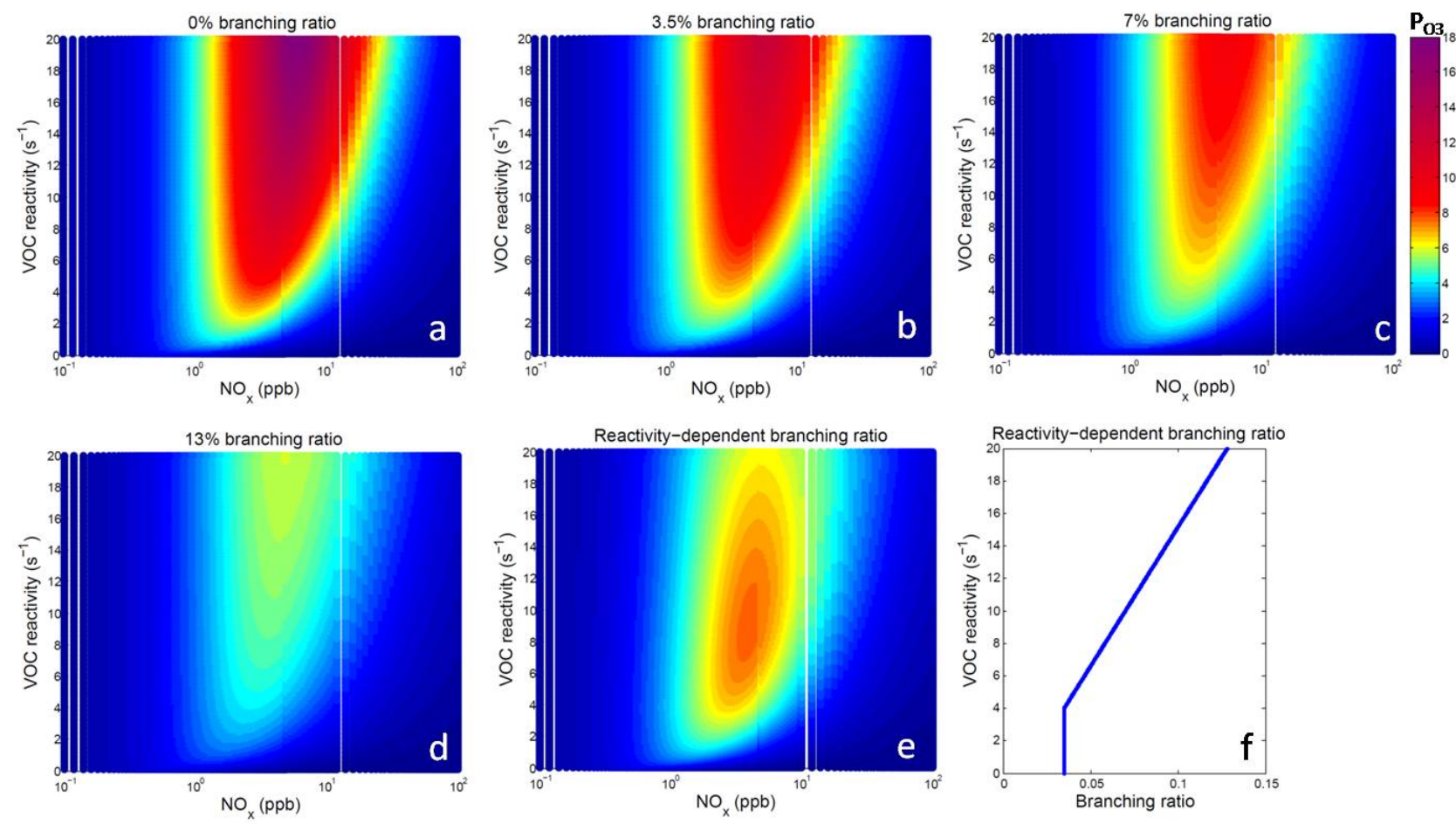

Fig. 1. Ozone production $\left(P_{\mathrm{O}_{3}}, \mathrm{ppbh}^{-1}\right)$ derived from an analytic model is plotted as a function of $\mathrm{NO}_{\mathrm{x}}$ and VOC reactivity under four different organic nitrate scenarios with branching ratios of $0 \%$ (a), 3.5\% (b), $7 \%$ (c), $13 \%$ (d) and a VOC-dependant branching ratio (e). Given a single organic nitrate branching ratio (a-d), increasing VOCs increases $P_{\mathrm{O}_{3}}$; in the $\mathrm{NO}_{\mathrm{x}}$-limited regime, increasing $\mathrm{NO}_{\mathrm{x}}$ increases $P_{\mathrm{O}_{3}}$ until a maximum is reached and the system becomes VOC-limited. Ignoring organic nitrate production severely over-estimates $P_{\mathrm{O}_{3}}$ maxima (a) compared to the $7 \%$ AN branching ratios scenario (b) observed in Mexico City. A scenario in which VOC decreases are accompanied by a reduction in branching ratio from 13 to $3.5 \%$ between VOC reactivities of 20 and $4 \mathrm{~s}^{-1}$ (f) demonstrates the case in which the $P_{\mathrm{O}_{3}}$ maximum is centered (e). Decreasing VOC reactivity may actually increase $P_{\mathrm{O}_{3}}$, counter to current thinking.

are only 1 or 2 . AN formation also affects the $\mathrm{NO}_{\mathrm{x}}$ concentration at which the system transitions from $\mathrm{NO}_{\mathrm{x}}$-limited to VOC-limited by a policy relevant percentage. For a given reactivity, maximum $P_{\mathrm{O}_{3}}$ occurs at a higher $\mathrm{NO}_{\mathrm{x}}$ when the calculation uses lower branching ratios. For example, at a reactivity of $4.5 \mathrm{~s}^{-1}$, ignoring AN formation $(\alpha=0 \%)$, we find peak $P_{\mathrm{O}_{3}}$ at $3.0 \mathrm{ppb} \mathrm{NO}_{\mathrm{x}}$; with a $7 \%$ branching ratio peak $P_{\mathrm{O}_{3}}$ occurs at $2.8 \mathrm{ppb} \mathrm{NO}$. This shift of peak- $\mathrm{NO}_{\mathrm{x}}$ increases with reactivity: the same branching ratio shift $(\alpha=0 \%$ to $7 \%$ ) at a higher reactivity of $9 \mathrm{~s}^{-1}$ results in a $13 \%$ change in the $\mathrm{NO}_{\mathrm{x}}$ where $P_{\mathrm{O}_{3}}$ peaks.

The strong suppression of $P_{\mathrm{O}_{3}}$ by AN formation shown in Fig. 1a-d implies that organic emission reductions that affect the branching ratios in Reaction (R2) will affect $P_{\mathrm{O}_{3}}$. For example, we have observed higher average branching rations in urban environs $(\alpha=5-10 \%)$ than in rural ones $(\alpha=3-4 \%)$ (Rosen et al., 2004; Perring et al., 2009, 2010). If we assume reducing VOC emissions results in a transition from an urban to rural VOC mix, then the reduction in $\alpha$ will lead to an increase in $\mathrm{O}_{3}$ production. Note that branching ratios for isoprene range from $4 \%$ to $12 \%$ (Tuazon et al., 1990; Chen et al., 1998; Sprengnether et al., 2002; Patchen et al., 2007;
Paulot et al., 2009; Perring et al., 2009), and that depending on the choice of urban mix and effective biogenic branching ratio, the effect on $P_{\mathrm{O}_{3}}$ would vary. To illustrate the effect we are describing, Fig. 1e shows a calculation of $P_{\mathrm{O}_{3}}$ for $\alpha$ decreasing from 0.13 to 0.035 as reactivity decreases from $20 \mathrm{~s}^{-1}$ to $4 \mathrm{~s}^{-1}$ (Fig. 1f). The figure demonstrates that accounting for the effects of $\mathrm{RONO}_{2}$ formation can fundamentally change the shape of the $P_{\mathrm{O}_{3}}$ contour map with a peak occurring in the center rather than the nearly vertical ridge line shown in Fig. 1a-d. Although there are a number of other metrics for considering the effects of VOC changes on $P_{\mathrm{O}_{3}}$ (e.g. incremental reactivity, ozone production potential, Pickering et al., 1990; FinlaysonPitts et al., 1997), to our knowledge none of these methods has a functional form capable of predicting an increase in ozone in response to VOC reductions.

This figure uses a larger branching ratio than we have observed in the atmosphere to exaggerate the effect we are describing. A more realistic scenario is useful to indicate how $\mathrm{RONO}_{2}$ chemistry would effect a policy relevant discussion of VOC vs. $\mathrm{NO}_{\mathrm{x}}$ reductions. For the purposes of evaluating policy options, it is common to consider examples where 
VOC or $\mathrm{NO}_{\mathrm{x}}$ emissions are reduced by about $30 \%$. Using that as a metric, in Fig. 2 we compare the effect of two hypothetical ozone reduction strategies to a reference case with $7 \%$ branching ratio and $\tau_{\mathrm{VOC}}=4.5 \mathrm{~s}^{-1}$ (the solid $P_{\mathrm{O}_{3}}$ curve in Fig. 2). In the first strategy we imagine uniform emission reductions that result in a $30 \%$ reduction in organic reactivity with no change to $\alpha$ (the lowest, dashed $P_{\mathrm{O}_{3}}$ curve in Fig. 2). The result is a decrease in $P_{\mathrm{O}_{3}}$ for $\mathrm{NO}_{\mathrm{x}}>0.7 \mathrm{ppb}$; this decrease changes with $\mathrm{NO}_{\mathrm{x}}$ mixing ratios, approaching $20 \%$ above $5 \mathrm{ppb} \mathrm{NO}_{\mathrm{x}}$. If instead the same $30 \%$ reduction of VOC reactivity occurs concurrently with a decrease in $\alpha$ from $7 \%$ to $3.5 \%$ (the dotted curve in Fig. 2) the result is mixed. At high $\mathrm{NO}_{\mathrm{x}}$ where $\mathrm{HNO}_{3}$ formation dominates chain termination, VOC controls are effective. In this example, VOC controls do not reduce $P_{\mathrm{O}_{3}}$ by at least $10 \%$ unless $\mathrm{NO}_{\mathrm{x}}$ is over $8 \mathrm{ppb}$. However, peak ozone production rates increase and ozone production increases at all values of $\mathrm{NO}_{\mathrm{x}}$ below $3 \mathrm{ppb}$, making it likely that ozone will increase at all locations downwind of the urban core. As a result of these calculations, we believe that much more careful attention to the effect of $\mathrm{RONO}_{2}$ formation on $P_{\mathrm{O}_{3}}$ will provide new insights into optimal urban $\mathrm{O}_{3}$ control strategies. We note that these calculations consider a single $\mathrm{NO}: \mathrm{NO}_{2}$ ratio, and that the assumptions required for Eq. (7) may not hold for the low-NO $\mathrm{N}_{\mathrm{x}}$ /high VOC reactivity regime of the upper left corner of Fig. 1a-e. For example, for a VOC reactivity of $5 \mathrm{~s}^{-1}$, the assumption that every $\mathrm{RO}_{2}$ reacts with $\mathrm{NO}$ is invalid at $\mathrm{NO}$ concentrations on the order of a ppt, as reactions with $\mathrm{HO}_{2}$ radicals become significant. At higher VOC reactivities, the break-down of the assumption occurs at higher $\mathrm{NO}_{\mathrm{x}}$ concentrations: for example, for an airmass with $20 \mathrm{~s}^{-1}$ VOC reactivity, the assumption required for Eq. (7) breaks down at $0.4 \mathrm{ppb} \mathrm{NO}$. Additionally, $\mathrm{HO}_{2}$ and $\mathrm{RO}_{2}$ radicals can react with $\mathrm{O}_{3}$,

$\mathrm{HO}_{2}+\mathrm{O}_{3} \rightarrow \mathrm{OH}+2 \mathrm{O}_{2}$

$\mathrm{RO}_{2}+\mathrm{O}_{3} \rightarrow \mathrm{RO}+2 \mathrm{O}_{2}$

Reaction (R8) produces $\mathrm{OH}$ radicals, thus effectively recycling $\mathrm{HO}_{\mathrm{x}}$ radicals. For $60 \mathrm{ppb} \mathrm{O}_{3}$, this reaction accounts for $>5 \%$ of the $\mathrm{HO}_{2}$ sinks when $\mathrm{NO}_{\mathrm{x}}$ is $<0.2 \mathrm{ppb}$ and $\mathrm{HO}_{2}$ is high. In parallel to $\mathrm{HO}_{2}, \mathrm{RO}_{2}+\mathrm{O}_{3}$ reactions effectively recycle $\mathrm{RO}_{2}+\mathrm{HO}_{2}$ radicals, and have no significant effect on the modeled $\mathrm{HO}_{\mathrm{x}}$ and $P_{\mathrm{O}_{3}}$. The reaction rate for Reaction (R9) is approximately 200 times slower than Reaction (R8) (Tyndall et al., 1998), and cannot compete with other $\mathrm{RO}_{2}$ reactions in our model system. While the NO: $\mathrm{NO}_{2}$ ratio depends on $\mathrm{O}_{3}$, $\mathrm{HO}_{2}$ and $\mathrm{RO}_{2}$, and thus varies, the algebraic solution presented is accurate for an instantaneous choice of those variables, and the values used in this manuscript are typical of observations made in Mexico City.

\subsection{Application to Mexico City}

To illustrate with an example, this chemistry is likely important to the options for ozone control in Mexico City. $\mathrm{O}_{3}$

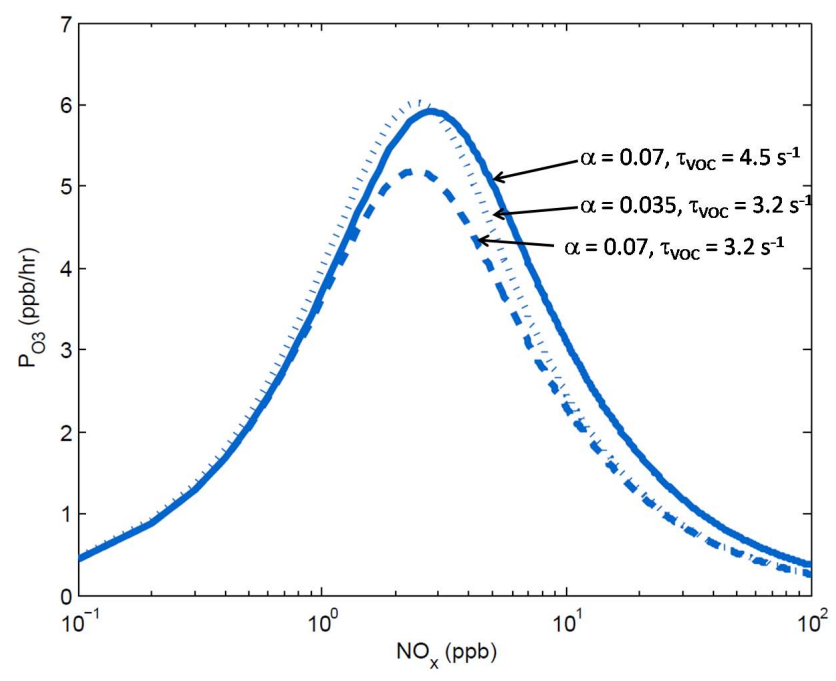

Fig. 2. Under three sample $\mathrm{VOC}-\mathrm{NO}_{\mathrm{x}}$ regimes, $P_{\mathrm{O}_{3}}$ varies as a function of $\mathrm{NO}_{\mathrm{x}}$ : for observed conditions in Mexico City (solid line; VOC reactivity of $4.5 \mathrm{~s}^{-1}$, ANs branching ratio of $7 \%$ ); a $30 \%$ reduction in VOC reactivity with no change in branching ratio (dashed line, $3.2 \mathrm{~s}^{-1}, 7 \%$ ), and a combined $30 \%$ reduction in VOC reactivity and subsequent $3.5 \%$ branching ratio, the result of targeted reduction in aromatics and other high-branching ratio VOCs (dotted line).

production in the Mexico City area is in a $\mathrm{NO}_{\mathrm{x}}$-suppressed regime (Lei et al., 2007; Tie et al., 2007). This is most evident in increased odd-oxygen levels on weekends in response to the decreased $\mathrm{NO}_{\mathrm{x}}$ concentrations (Stephens et al., 2008). Long-term studies show that $\mathrm{NO}_{\mathrm{x}}$ and $\mathrm{CO}$ decreased over the last 20 yr by 10 and $70 \%$, respectively (Arriaga-Colina et al., 2004; Stephens et al., 2008). Total VOC concentrations have been essentially constant (Arriaga-Colina et al., 2004). PAN concentrations have decreased from daily maxima of 34 to $15 \mathrm{ppb}$ between 1997 and 2003. This is a steeper decrease than in $\mathrm{NO}_{\mathrm{x}}$ and is likely due to reduced emissions of specific hydrocarbons (Marley et al., 2007).

As described in Sect. 2.3, we use the slope of the $\mathrm{O}_{\mathrm{x}}-$ $\Sigma$ ANs correlation (Fig. 3) to derive an effective branching ratio $\alpha$ of $7 \pm 1 \%(1 \sigma)$. Observations of $\mathrm{C}_{1}-\mathrm{C}_{4}$ ANs show they account for $5-10 \%$ of the observed $\Sigma$ ANs. We estimate fractional contributions of observed organics to the total $\Sigma$ ANs, finding that $5 \%$ of alkyl nitrates are derived from oxidation of $\mathrm{C}_{1}$ to $\mathrm{C}_{4}$ alkanes, $10-26 \%$ are derived from aromatic VOCs, and $29-35 \%$ are derived from unsaturated hydrocarbons (Fig. S1). Longer-chain saturated hydrocarbons are $24-29 \%$ of the AN precursors and $\Sigma$ ANs themselves 8$10 \%$. The predicted branching ratio is $4 \%$, about half of what we observe, indicating that there are additional high AN yield compounds that were not measured; the predicted branching ratio is similar to the difference between AN yields inferred from the $\mathrm{O}_{3}-\Sigma \mathrm{AN}$ correlation and observed VOC in other urban areas including Sacramento and Houston (Rosen 


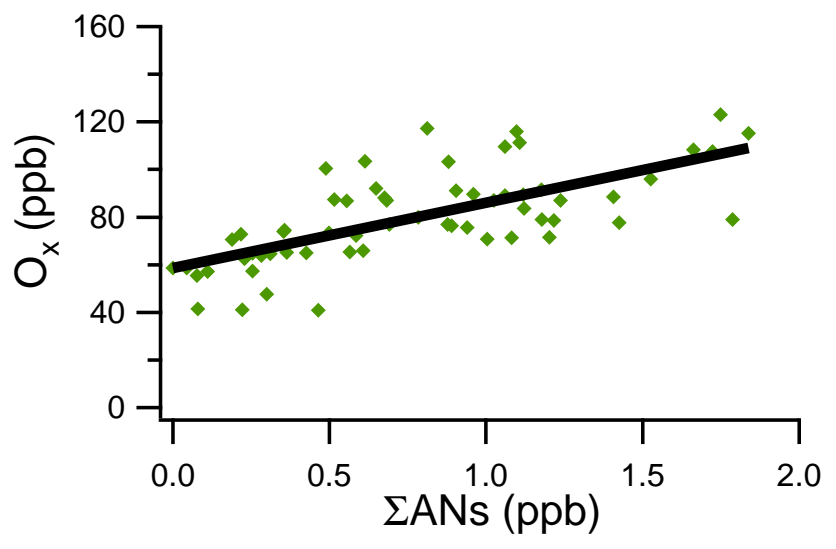

Fig. 3. The net branching ratio of $7 \%$ for total alkyl nitrates in the Mexico City region is calculated from the slope $\left(27 \mathrm{ppb} \mathrm{ppb}^{-1}\right)$ of the correlation of $\mathrm{O}_{\mathrm{x}}\left(\mathrm{NO}_{2}+\mathrm{O}_{3}\right)$ and $\Sigma \mathrm{ANs}$ observations.

et al., 2004; Cleary et al., 2005). These results from the Tecamac ground site are consistent with concurrent aircraft observations taken in and downwind of the Mexico City plume (Perring et al., 2010).

As the effective $\alpha$ is so high (larger than we have observed in other cities), it is reasonable to imagine that control strategies targeting $\mathrm{O}_{3}$ or particulate matter would alter the effective branching ratio of the hydrocarbon mixture in Mexico City. This could occur as a transition to a rural mixture dominated by lower- $\alpha_{i}$ VOCs as described in the theoretical example above, or by direct management of anthropogenic emissions. For example, long chain hydrocarbons are thought to be important to secondary organic aerosol (SOA) and might be deliberately reduced in an attempt to lower SOA. These chemicals also have some of the largest branching ratios $(\sim 30 \%)$ to AN formation (Lim et al., 2009). We calculate that an emission control strategy resulting in a selective $50 \%$ reduction of the $\mathrm{C}_{5}$ and larger alkanes that we measured would reduce VOC reactivity by $4 \%$ and $\alpha$ by $14 \%$. Starting with the reference case in Fig. 2 $\left(4.5 \mathrm{~s}^{-1}, \alpha=7 \%\right)$, this change would increase peak $P_{\mathrm{O}_{3}}$ from $5.9 \mathrm{ppbh}^{-1}$ to $6.1 \mathrm{ppbh}^{-1}$. Note that if the AN branching ratio effect on $P_{\mathrm{O}_{3}}$ described in this paper is ignored (i.e., $\alpha=0$ ), a $4 \%$ reduction in VOC reactivity from $4.5 \mathrm{~s}^{-1}$ reduces peak $P_{\mathrm{O}_{3}}$ in this model from 8.4 to $8.2 \mathrm{ppbh}^{-1}$. It is now believed that a class of intermediate volatility organic compounds (IVOC) are not measured by current techniques but react rapidly to form SOA in urban plumes (Robinson et al., 2007). These IVOC would have high $(\sim 30 \%)$ AN yields. If we assume they are an additional $4 \%$ of the reactivity, removal of these molecules would increase $P_{\mathrm{O}_{3}}$ by $6 \%$ to $6.3 \mathrm{ppbh}^{-1}$. Similarly, AN formation from aromatics are estimated to occur more efficiently than the average VOC (Atkinson et al., 2003; Wagner et al., 2003). Aromatics have been dramatically reduced in the US through use of reformulated fuels and one might imagine a similar control strategy could be implemented in Mexico City. However, the branching ratios for aromatics are poorly known for the first oxidation stage and completely unknown for subsequent oxidation steps. As described above (Sect. 2.4), we calculate aromatic ANs yields with both low and high branching ratios. The higher values are intended to represent the possible range for chemical production of ANs in subsequent stages of aromatic oxidation. Aromatic precursors contribute $10 \%$ of $\Sigma$ ANs for the lower yields and $26 \%$ for higher yields. The higher yields raise the effective branching ratio by 17 $19 \%$, depending on whether potential IVOC are included in the calculation. Complete removal of aromatics would either result in no change in the $P_{\mathrm{O}_{3}}$ maximum $\left(5.9 \mathrm{ppb} \mathrm{h}^{-1}\right.$, low aromatic branching ratios) or increase the $P_{\mathrm{O}_{3}}$ maximum by $3 \%$ to $6.1 \mathrm{ppbh}^{-1}$ (high aromatic branching ratios). If instead of complete removal we imagine $50 \%$ removal of $\mathrm{C}_{5}$ and larger alkanes, IVOC and aromatics, we predict that peak $P_{\mathrm{O}_{3}}$ would increase by 5-6\%. These effects are magnified for systems with higher VOC reactivity: for a system with twice the VOC reactivity $\left(9 \mathrm{~s}^{-1}\right)$, a $50 \%$ removal of $\mathrm{C}_{5}$ and larger alkanes, IVOC and aromatics would result in an 8-9\% increase in the $P_{\mathrm{O}_{3}}$ maximum. It should be noted that the history of air quality control measures has focused on reducing vapor pressure - an action which had the likely consequence of increasing $\alpha$, while current trends toward replacing gasoline with higher vapor pressure fuels (e.g. ethanol) act in the converse to decrease $\alpha$.

Perring et al. (2010) demonstrated that the $\Sigma$ AN branching ratio can decrease with photochemical age as an urban plume evolves, changing from $12 \%$ to $2 \%$ with $50 \mathrm{~h}$ of processing. This is consistent with ground-based observations that branching ratios in urban areas are typically higher than in rural areas, suggesting that the concurrent effect of changing VOC mix and $\Sigma$ AN branching ratios on $P_{\mathrm{O}_{3}}$ is relevant over a wide range of atmospherically relevant regimes (Perring et al., 2010).

\section{Conclusions}

AN formation, a relatively minor reaction that is more or less ignored in the standard models guiding air pollution control strategies, is surprisingly important. We show both in a model and with a real world example of Mexico City that the effects of AN formation can counteract the benefits of VOC reductions on ozone production. Under circumstances of significant photochemistry and high VOC reactivity, removing VOCs can change the effective $\Sigma$ AN branching ratio, potentially increasing $\mathrm{O}_{3}$ production and changing the $\mathrm{NO}_{\mathrm{x}}$ and VOC dependence of $P_{\mathrm{O}_{3}}$. This chemistry may also be a partial explanation for why ozone reductions are slowing in Los Angeles, a city where VOC controls have until recently been effective. Independent of these two examples, the effect of $\mathrm{AN}$ production on $\mathrm{O}_{3}$ formation rates indicates that additional thought should be given to AN formation in 
designing air quality control strategies and additional attention should be given to understanding the chemical mechanisms for production of ANs and to accurately representing them in the photochemical mechanisms used for air quality modeling. At present, chemical mechanisms used in urban and regional air quality models do not treat $\mathrm{AN}$ formation in detail in the first stage of oxidation, let alone in the subsequent ones. The problem may be even more severe for multifunctional oxidation products for which there are relatively few constraints from the laboratory. Until the mechanisms in such models are evaluated, approximate calculations could be used to supplement those models in planning.

\section{Supplementary material related to this article is available online at: http://www.atmos-chem-phys.net/11/4085/2011/ acp-11-4085-2011-supplement.pdf.}

Acknowledgements. The authors thank Joost de Gouw from NOAA-ESRL for additional VOC data. This research was funded by NSF grants ATM-0639847 and ATM-0511829.

Edited by: I. Trebs

\section{References}

Arriaga-Colina, J. L., West, J. J., Sosa, G., Escalona, S. S., Ordunez, R. M., and Cervantes, A. D. M.: Measurements of VOCs in Mexico City (1992-2001) and evaluation of VOCs and CO in the emissions inventory, Atmos. Environ., 38, 2523-2533, 2004.

Atkinson, R. and Arey, J.: Gas-phase tropospheric chemistry of biogenic volatile organic compounds: a review, Atmos. Environ., 37, S197-S219, 2003.

Bell, M. L., Dominici, F., and Samet, J. M.: A meta-analysis of time-series studies of ozone and mortality with comparison to the national morbidity, mortality, and air pollution study, Epidemiology, 16, 436-445, 2005.

Booker, F., Muntifering, R., McGrath, M., Burkey, K., Decoteau, D., Fiscus, E., Manning, W., Krupa, S., Chappelka, A., and Grantz, D.: The Ozone Component of Global Change: Potential Effects on Agricultural and Horticultural Plant Yield, Product Quality and Interactions with Invasive Species, J. Int. Plant Biol., 51, 337-351, 2009.

Chen, X. H., Hulbert, D., and Shepson, P. B.: Measurement of the organic nitrate yield from $\mathrm{OH}$ reaction with isoprene, J. Geophys. Res., 103, 25563-25568, 1998.

Cleary, P. A., Murphy, J. G., Wooldridge, P. J., Day, D. A., Millet, D. B., McKay, M., Goldstein, A. H., and Cohen, R. C.: Observations of total alkyl nitrates within the Sacramento Urban Plume, Atmos. Chem. Phys. Discuss., 5, 4801-4843, doi:10.5194/acpd5-4801-2005, 2005.

Day, D. A., Wooldridge, P. J., Dillon, M. B., Thornton, J. A., and Cohen, R. C.: A thermal dissociation laser-induced fluorescence instrument for in situ detection of $\mathrm{NO}_{2}$, peroxy nitrates, alkyl nitrates, and $\mathrm{HNO}_{3}$, J. Geophys. Res., 107, 4046, doi:10.1029/2001JD000779, 2002.
Day, D. A., Dillon, M. B., Wooldridge, P. J., Thornton, J. A., Rosen, R. S., Wood, E. C., and Cohen, R. C.: On alkyl nitrates, $\mathrm{O}_{3}$, and the "missing $\mathrm{NO}_{\mathrm{y}}$ ", J. Geophys. Res., 108, 4501, doi:10.1029/2003JD003685, 2003.

Dunlea, E. J., Herndon, S. C., Nelson, D. D., Volkamer, R. M., San Martini, F., Sheehy, P. M., Zahniser, M. S., Shorter, J. H., Wormhoudt, J. C., Lamb, B. K., Allwine, E. J., Gaffney, J. S., Marley, N. A., Grutter, M., Marquez, C., Blanco, S., Cardenas, B., Retama, A., Ramos Villegas, C. R., Kolb, C. E., Molina, L. T., and Molina, M. J.: Evaluation of nitrogen dioxide chemiluminescence monitors in a polluted urban environment, Atmos. Chem. Phys., 7, 2691-2704, doi:10.5194/acp-7-2691-2007, 2007.

Fast, J. D., de Foy, B., Acevedo Rosas, F., Caetano, E., Carmichael, G., Emmons, L., McKenna, D., Mena, M., Skamarock, W., Tie, X., Coulter, R. L., Barnard, J. C., Wiedinmyer, C., and Madronich, S.: A meteorological overview of the MILAGRO field campaigns, Atmos. Chem. Phys., 7, 2233-2257, doi:10.5194/acp-7-2233-2007, 2007.

FinlaysonPitts, B. J. and Pitts, J. N.: Tropospheric air pollution: Ozone, airborne toxics, polycyclic aromatic hydrocarbons, and particles, Science, 276, 1045-1052, 1997.

Heald, C. L., Jacob, D. J., Fiore, A. M., Emmons, L. K., Gille, J. C., Deeter, M. N., Warner, J., Edwards, D. P., Crawford, J. H., Hamlin, A. J., Sachse, G. W., Browell, E. V., Avery, M. A., Vay, S. A., Westberg, D. J., Blake, D. R., Singh, H. B., Sandholm, S. T., Talbot, R. W., and Fuelberg, H. E.: Asian outflow and transPacific transport of carbon monoxide and ozone pollution: An integrated satellite, aircraft, and model perspective, J. Geophys. Res., 108, 4804, doi:10.1029/2003JD003507, 2003.

Horowitz, L. W., Fiore, A. M., Milly, G. P., Cohen, R. C., Perring, A., Wooldridge, P. J., Hess, P. G., Emmons, L. K., and Lamarque, J. F.: Observational constraints on the chemistry of isoprene nitrates over the eastern United States, J. Geophys. Res., 112, D12S08, doi:10.1029/2006JD007747, 2007.

Hudman, R. C., Jacob, D. J., Cooper, O. R., Evans, M. J., Heald, C. L., Park, R. J., Fehsenfeld, F., Flocke, F., Holloway, J., Hubler, G., Kita, K., Koike, M., Kondo, Y., Neuman, A., Nowak, J., Oltmans, S., Parrish, D., Roberts, J. M., and Ryerson, T.: Ozone production in transpacific Asian pollution plumes and implications for ozone air quality in California, J. Geophys. Res., 109, D23S10, doi:10.1029/2004JD004974, 2004.

Ito, A., Sillman, S. and Penner, J. E.: Global chemical transport model study of ozone response to changes in chemical kinetics and biogenic volatile organic compounds emissions due to increasing temperatures: Sensitivities to isoprene nitrate chemistry and grid resolution, J. Geophys. Res., 114, D09301, doi:10.1029/2008JD011254, 2009.

Lei, W., de Foy, B., Zavala, M., Volkamer, R., and Molina, L. T.: Characterizing ozone production in the Mexico City Metropolitan Area: a case study using a chemical transport model, Atmos. Chem. Phys., 7, 1347-1366, doi:10.5194/acp-7-1347-2007, 2007.

Lim, Y. B. and Ziemann, P. J.: Effects of Molecular Structure on Aerosol Yields from $\mathrm{OH}$ Radical-Initiated Reactions of Linear, Branched, and Cyclic Alkanes in the Presence of $\mathrm{NO}_{\mathrm{x}}$, Environ. Sci. Technol., 43, 2328-2334, 2009.

Liu, S. C. and Trainer, M.: Responses of the Tropospheric Ozone and Odd Hydrogen Radicals to Column Ozone Change, J. Atmos. Chem., 6, 221-233, 1988. 
Marley, N. A., Gaffney, J. S., Ramos-Villegas, R., and Cárdenas González, B.: Comparison of measurements of peroxyacyl nitrates and primary carbonaceous aerosol concentrations in Mexico City determined in 1997 and 2003, Atmos. Chem. Phys., 7, 2277-2285, doi:10.5194/acp-7-2277-2007, 2007.

Moxim, W. J., Levy, H., and Kasibhatla, P. S.: Simulated global tropospheric PAN: Its transport and impact on $\mathrm{NO}_{\mathrm{x}}$, J. Geophys. Res., 101, 12621-12638, 1996.

Murphy, J. G., Day, D. A., Cleary, P. A., Wooldridge, P. J., Millet, D. B., Goldstein, A. H., and Cohen, R. C.: The weekend effect within and downwind of Sacramento: Part 2. Observational evidence for chemical and dynamical contributions, Atmos. Chem. Phys. Discuss., 6, 11971-12019, doi:10.5194/acpd6-11971-2006, 2006.

Murphy, J. G., Day, D. A., Cleary, P. A., Wooldridge, P. J., Millet, D. B., Goldstein, A. H., and Cohen, R. C.: The weekend effect within and downwind of Sacramento - Part 1: Observations of ozone, nitrogen oxides, and VOC reactivity, Atmos. Chem. Phys., 7, 5327-5339, doi:10.5194/acp-7-5327-2007, 2007.

Parrish, D. D., Holloway, J. S., and Fehsenfeld, F. C.: Routine, Continuous Measurement of Carbon-Monoxide with Parts-PerBillion Precision, Environ. Sci. Technol., 28, 1615-1618, 1994.

Patchen, A. K., Pennino, M. J., Kiep, A. C., and Elrod, M. J.: Direct kinetics study of the product-forming channels of the reaction of isoprene-derived hydroxyperoxy radicals with NO, Int. J. Chem. Kinet., 39, 353-361, 2007.

Paulot, F., Crounse, J. D., Kjaergaard, H. G., Kroll, J. H., Seinfeld, J. H., and Wennberg, P. O.: Isoprene photooxidation: new insights into the production of acids and organic nitrates, Atmos. Chem. Phys., 9, 1479-1501, doi:10.5194/acp-9-1479-2009, 2009.

Perring, A. E., Bertram, T. H., Wooldridge, P. J., Fried, A., Heikes, B. G., Dibb, J., Crounse, J. D., Wennberg, P. O., Blake, N. J., Blake, D. R., Brune, W. H., Singh, H. B., and Cohen, R. C.: Airborne observations of total $\mathrm{RONO}_{2}$ : new constraints on the yield and lifetime of isoprene nitrates, Atmos. Chem. Phys., 9, 1451-1463, doi:10.5194/acp-9-1451-2009, 2009.

Perring, A. E., Bertram, T. H., Farmer, D. K., Wooldridge, P. J., Dibb, J., Blake, N. J., Blake, D. R., Singh, H. B., Fuelberg, H., Diskin, G., Sachse, G., and Cohen, R. C.: The production and persistence of $\Sigma \mathrm{RONO}_{2}$ in the Mexico City plume, Atmos. Chem. Phys., 10, 7215-7229, doi:10.5194/acp-10-7215-2010, 2010.

Pickering, K. E., Thompson, A. M., Dickerson, R. R., Luke, W. T., McNamara, D. P., Greenberge, J. P., and Zimmerman, P. R.: Model calculations of tropospheric ozone production potential following observed convective events, J. Geophys. Res., 95, 14049-14062, 1990.

Robinson, A. L., Donahue, N. M., Shrivastava, M. K., Weitkamp, E. A., Sage, A. M., Grieshop, A. P., Lane, T. E., Pierce, J. R., and Pandis, S. N.: Rethinking organic aerosols: Semivolatile emissions and photochemical aging, Science, 315, 1259-1262, 2007.

Rollins, A. W., Smith, J. D., Wilson, K. R., and Cohen, R. C.: Real Time In Situ Detection of Organic Nitrates in Atmospheric Aerosols, Environ. Sci. Technol., 44, 5540-5545, 2010.

Rosen, R. S., Wood, E. C., Wooldridge, P. J., Thornton, J. A., Day, D. A., Kuster, W., Williams, E. J., Jobson, B. T., and Cohen, R. C.: Observations of total alkyl nitrates during Texas Air Quality Study 2000: Implications for $\mathrm{O}_{3}$ and alkyl nitrate photochemistry, J. Geophys. Res., 109, D07303, doi:10.1029/2003JD004227, 2004.

Ryerson, T. B., Williams, E. J., and Fehsenfeld, F. C.: An efficient photolysis system for fast-response $\mathrm{NO}_{2}$ measurements, J. Geophys. Res., 105, 26447-26461, 2000.

Sander, S. P., Finlayson-Pitts, B. J., Friedl, R. R., Golden, D. M., Huie, R. E., Keller-Rudek, H., Kolb, C. E., Kurylo, M. J., Molina, M. J., Moortgat, G. K., Orkin, V. L., Ravishankara, A. R., and Wine, P. H.: Chemical kinetics and photochemical data for use in atmospheric studies, Evaluation Number 15 in JPL Publication 06-2, Jet Propulsion Laboratory, 2006.

Selin, N. E., Wu, S., Nam, K. M., Reilly, J. M., Paltsev, S., Prinn, R. G., and Webster, M. D.: Global health and economic impacts of future ozone pollution, Environ. Res. Lett., 4, 044014 , doi:10.1088/1748-9326/4/4/044014, 2009.

Shepson, P. B., Anlauf, K. G., Bottenheim, J. W., Wiebe, H. A., Gao, N., Muthuramu, K., and Mackay, G. I.: Alkyl Nitrates and Their Contribution to Reactive Nitrogen at a Rural Site in Ontario (Vol 27a, Pg 749, 1993), Atmos. Environ., 27, 2251-2251, 1993.

Silverman, R. A. and Ito, K.: Age-related association of fine particles and ozone with severe acute asthma in New York City, Journal of Allergy and Clinical Immunology, 125, 367-373, 2010.

Singh, H. B. and Hanst, P. L.: Peroxyacetyl Nitrate (Pan) in the Unpolluted Atmosphere - an Important Reservoir for NitrogenOxides, Geophys. Res. Lett., 8, 941-944, 1981.

Sprengnether, M., Demerjian, K. L., Donahue, N. M., and Anderson, J. G.: Product analysis of the $\mathrm{OH}$ oxidation of isoprene and 1,3-butadiene in the presence of NO, J. Geophys. Res., 107, 4268, doi:10.1029/2001JD000716, 2002.

Stephens, S., Madronich, S., Wu, F., Olson, J. B., Ramos, R., Retama, A., and Muñoz, R.: Weekly patterns of México City's surface concentrations of $\mathrm{CO}, \mathrm{NO}_{\mathrm{x}}, \mathrm{PM}_{10}$ and $\mathrm{O}_{3}$ during 19862007, Atmos. Chem. Phys., 8, 5313-5325, doi:10.5194/acp-85313-2008, 2008.

Thornton, J. A., Wooldridge, P. J., Cohen, R. C., Martinez, M., Harder, H., Brune, W. H., Williams, E. J., Roberts, J. M., Fehsenfeld, F. C., Hall, S. R., Shetter, R. E., Wert, B. P., and Fried, A.: Ozone production rates as a function of $\mathrm{NO}_{\mathrm{x}}$ abundances and $\mathrm{HO}_{\mathrm{x}}$ production rates in the Nashville urban plume, J. Geophys. Res., 107, 4146, doi:10.1029/2001JD000932, 2002.

Tie, X. X., Madronich, S., Li, G. H., Ying, Z. M., Zhang, R. Y., Garcia, A. R., Lee-Taylor, J., and Liu, Y. B.: Characterizations of chemical oxidants in Mexico City: A regional chemical dynamical model (WRF-Chem) study, Atmos. Environ., 41, 1989-2008, 2007.

Tuazon, E. C. and Atkinson, R.: A Product Study of the Gas-Phase Reaction of Isoprene with the Oh Radical in the Presence of $\mathrm{NO}_{\mathrm{x}}$, Int. J. Chem. Kinet., 22, 1221-1236, 1990.

Tyndall, G. S., Wallington, T. J., and Ball, J. C.: FTIR product study of the reactions $\mathrm{CH} 3 \mathrm{O} 2+\mathrm{CH} 3 \mathrm{O} 2$ and $\mathrm{CH}_{3} \mathrm{O}_{2}+\mathrm{O}-3$, J. Phys. Chem. A, 102, 2547-2554, 1998.

Wagner, V., Jenkin, M. E., Saunders, S. M., Stanton, J., Wirtz, K, and Pilling, M. J.: Modelling of the photooxidation of toluene: conceptual ideas for validating detailed mechanisms, Atmos. Chem. Phys., 3, 89-106, doi:10.5194/acp-3-89-2003, 2003.

Warneke, C., de Gouw, J. A., Lovejoy, E. R., Murphy, P. C., Kuster, W. C., and Fall, R.: Development of proton-transfer ion trap-mass spectrometry: On-line detection and identification of volatile organic compounds in air, J. Am. Soc. Mass Spectrom., 
16, 1316-1324, 2005.

Weaver, C. P., Liang, X. Z., Zhu, J., Adams, P. J., Amar, P., Avise, J., Caughey, M., Chen, J., Cohen, R. C., Cooter, E., Dawson, J. P., Gilliam, R., Gilliland, A., Goldstein, A. H., Grambsch, A., Grano, D., Guenther, A., Gustafson, W. I., Harley, R. A., He, S., Hemming, B., Hogrefe, C., Huang, H. C., Hunt, S. W., Jacob, D. J., Kinney, P. L., Kunkel, K., Lamarque, J. F., Lamb, B., Larkin, N. K., Leung, L. R., Liao, K. J., Lin, J. T., Lynn, B. H., Manomaiphiboon, K., Mass, C., McKenzie, D., Mickley, L. J., O'Neill, S. M., Nolte, C., Pandis, S. N., Racherla, P. N., Rosenzweig, C., Russell, A. G., Salathe, E., Steiner, A. L., Tagaris, E., Tao, Z., Tonse, S., Wiedinmyer, C., Williams, A., Winner, D. A., Woo, J. H., Wu, S., and Wuebbles, D. J.: A Preliminary Synthesis of Modeled Climate Change Impacts on Us Regional Ozone Concentrations, B. Am. Meteorol. Soc., 90, 1843-1863, 2009.
Wooldridge, P. J., Perring, A. E., Bertram, T. H., Flocke, F. M., Roberts, J. M., Singh, H. B., Huey, L. G., Thornton, J. A., Wolfe, G. M., Murphy, J. G., Fry, J. L., Rollins, A. W., LaFranchi, B. W., and Cohen, R. C.: Total Peroxy Nitrates ( $\Sigma$ PNs) in the atmosphere: the Thermal Dissociation-Laser Induced Fluorescence (TD-LIF) technique and comparisons to speciated PAN measurements, Atmos. Meas. Tech., 3, 593-607, doi:10.5194/amt-3-5932010, 2010.

Wu, S. L., Mickley, L. J., Jacob, D. J., Logan, J. A., Yantosca R. M., and Rind, D.: Why are there large differences between models in global budgets of tropospheric ozone?, J. Geophys. Res., 112, D05302, doi:10.1029/2006JD007801, 2007. 